\title{
Renewable Energy Resources Impact on Clean Electrical Power by developing the North-West England Hydro Resource Model
}

\author{
Philip Leigh $^{1}$, George Aggidis ${ }^{1}$, David Howard ${ }^{2}$ and Bob Rothschild ${ }^{3}$ \\ ${ }^{1}$ Lancaster University, Department of Engineering, Bailrigg, Lancaster, LA1 4YR, England \\ ${ }^{2}$ Centre for Ecology and Hydrology, Lancaster Environment Centre, Bailrigg, Lancaster, LA1 4AP, England \\ ${ }^{3}$ Lancaster University, Department of Economics, Lancaster University, Bailrigg, Lancaster, LA1 4YR, England
}

\begin{abstract}
This paper describes the development of a sequential decision support system to promote hydroelectric power in North-West England. The system, composed of integrated models, addresses barriers to the installation of hydroelectric power schemes. Information is linked through an economic assessment which identifies different turbine options, assesses their suitability for location and demand; and combines the different types of information in a way that supports decision making.

The system is structured into five components: the hydrological resource is modelled using Low Flows 2000, the turbine options are identified from hydrological, environmental and demand requirements; and the consequences of different solutions will be fed into other components so that the environmental impacts and public acceptability can be assessed and valued.

A preliminary case study is presented on an old gunpowder works to illustrate how the resource model may be employed. Historical architectural structures, power uptake and educational instruction of hydro power technology are considered.
\end{abstract}

Index Terms -- Flow duration curve, Hydroelectric power, North-West England, Sequential decision making.

\section{INTRODUCTION}

There is political recognition that our reliance on fossil fuels is non sustainable; nuclear power may not be capable of providing the complete solution - where does that leave us? Much recent sustainable energy generation has focused on wind power, which is intermittent. Bioenergy would require a major shift in land use. This paper explores the potential capacity of an often overlooked renewable energy source, namely micro scale hydro power. DEFRA has stated that if many streams and rivers in the UK could be tapped it would be possible to produce around 10,000 GWh per year - enough to meet over $3 \%$ of UK current total energy requirements; making a significant contribution to the Government's renewable energy target of $10 \%$ by 2010 , [1]. Additionally, as a clean power source hydro can help attain national targets for $\mathrm{CO}_{2}$ reduction.

One much discussed element of the British weather is rain; especially in the west of the country. We receive reliable annual precipitation rates of approximately $1 \mathrm{~m}-$
$3 \mathrm{~m}$ (depending on location and altitude); this coupled with a complex terrain generated array of mountain streams through to lowland rivers, has the potential to convert moving water (kinetic energy) into electricity via a turbine for both ultra low $(<2 \mathrm{~m})$, low $(2-20 \mathrm{~m})$ and medium/high heads $(>20 \mathrm{~m})$. In the UK our largest energy demands occur during autumn through to spring. In general, this coincides with the period of highest water flow; making hydro often more attractive than other renewable energy sources such as solar power.

Lancaster University on behalf of the Joule Centre (http://www.joulecentre.org/), and the North West Development Agency (NWDA), (http://nwda.co.uk) has been awarded a grant to investigate the potential of hydro power in North West England. The project entitled "North West Hydro Resource Model" aims to build a web based tool; which will enable interested parties to ask whether hydro power could be harnessed to provide all or a proportion of their individual or community electricity requirements, [2 - 5].

\section{Sequential Decision Making Process}

A number of leading Lancaster academics across many departments in partnership with the Centre for Ecology and Hydrology (CEH) and Hydrological Solutions (HS) in Wallingford have come together in an attempt to address this problem. The model will be an iterative process and Lancaster University is approaching it from a systems and informatics standpoint [6]. To be economically viable, any energy system has to recover its costs over a defined period - the payback time? Thus, the main decision of any hydro power scheme is economic. This key element will ultimately determine if a project moves from conception to completion. In-between there are many other phases and steps.

Figure 1 shows a circuit that takes linked information around an iterative loop in a "Sequential Decision Making" (SDM) process, [7]. This process requires the user to ask a number of questions at each of the main topic headings within the sequence before moving to the next topic or level. Within this project topics are defined as work packages (http://www.engineering.lancs.ac.uk/ REGROUPS/LUREG/home.htm). 


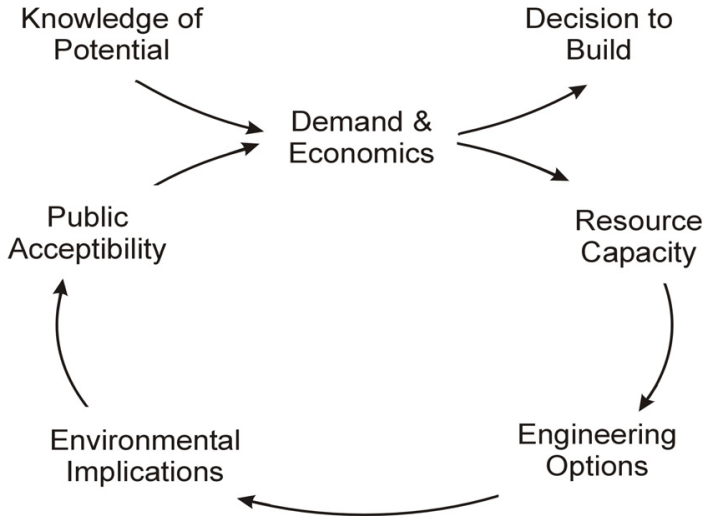

Fig. 1: Sequential Decision Making Process.

It is envisaged the user will progress round the loop several times, resulting in a multi level sequential decision making process (figure 2); questioning the strength and confidence at the end of each loop. This process allows refinement of questioning in order to obtain a higher level of sophistication and accuracy in the answers, and permits the user to short circuit the loop where applicable in order to move their individual project forward [8]. The SDM process is designed to develop a generic and fundamental understanding of the barriers to the deployment of hydro electric schemes in North-West England.

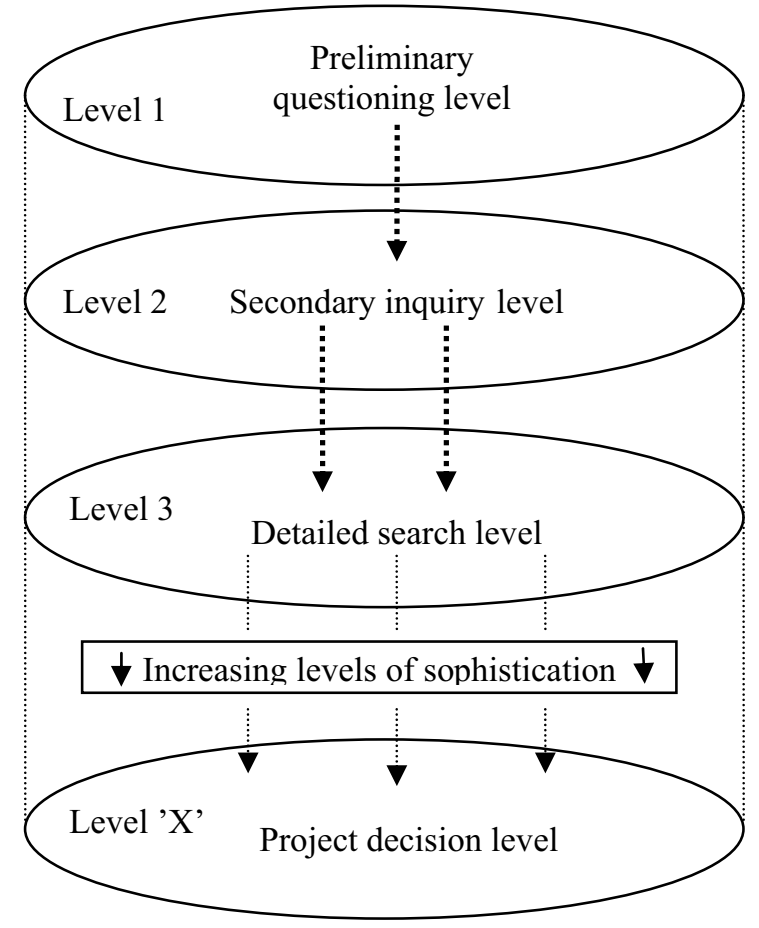

Fig. 2: Multi-Level Sequential Decision Making Process.

\section{A. Modelling}

The modelling approaches being employed will differ within each component, using mathematical, statistical and economic analysis. The outputs will be presented in a range of formats enabling use of the results to be made by different users. The model is seen as a tactical tool that will operate at the level of individual low- and ultra-low head hydro installations and there is interest from potential users across a range of scales from large utilities and national agencies to local manufacturers.

\section{B. Validation}

The development of the model will include field validation of any forecast figures and will identify the necessary monitoring and gauging to identify measures that can rapidly and easily be taken to confirm confidence in the proposed solution. It is intended that the system, once initiated, could be developed further for use outside North-West England.

\section{WORK PACKAGES}

The North-West England hydro resource project comprises of 6 main Work Packages (WP's). These are:

\section{A. (WP1) Demand and economics}

This work package addresses identified costs and revenues associated with various turbine technologies. Cost per kilowatt hour produced $(\mathrm{p} / \mathrm{kWh})$ is a key element of any proposed hydro power system. WP1 will also investigate costs and benefits for a community, e.g. loss of amenity and degradation of the physical environment.

Connection to the grid can be a costly component of a hydro power scheme and must be included in the overall budget (figure 3 ).

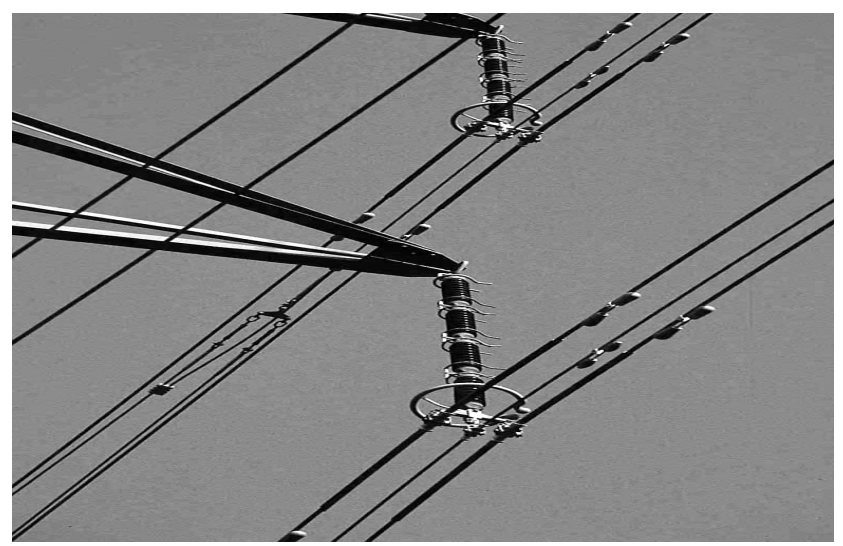

Fig. 3: Grid connection is a key factor in any hydro scheme that cannot use all generated power on site.

\section{B. (WP2) Resource capacity}

Here we will utilise expertise from HS Wallingford and Low Flows 2000 software to estimate flow duration curves for different river and stream reaches and identify sub catchments [9], (figure 4).

Uncertainty in the prediction of flow duration curves will be constrained to minimise and express uncertainty in projected energy production in order to demonstrate the viability of a scheme. 


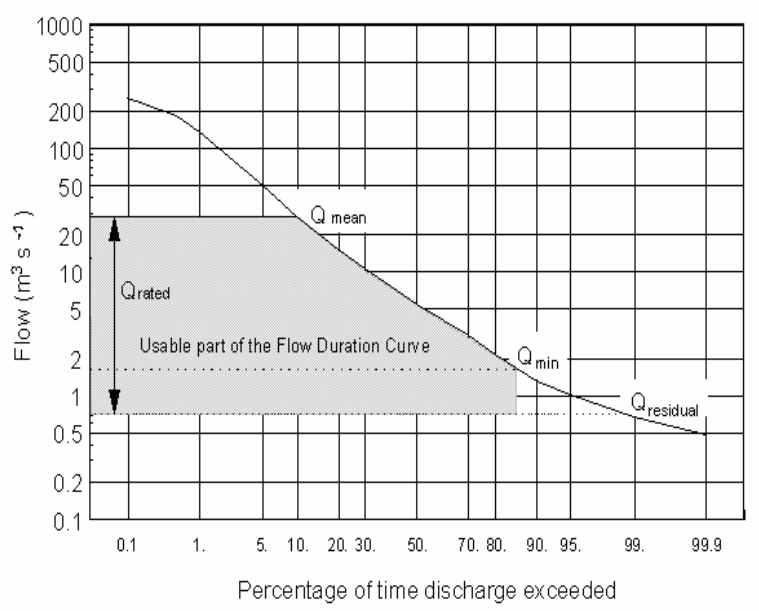

Fig. 4: Example of a typical flow duration curve.

\section{C. (WP3) Engineering options}

Modern hydro turbine design allows for small turbine units to be installed directly into a small stream or water course. GIS data combined with flow data established from WP2 will feed into advanced software tools to optimise the engineering options on cost and annual generated power; all latest engineering innovations will be incorporated in this model, [10,11], (figure 5).

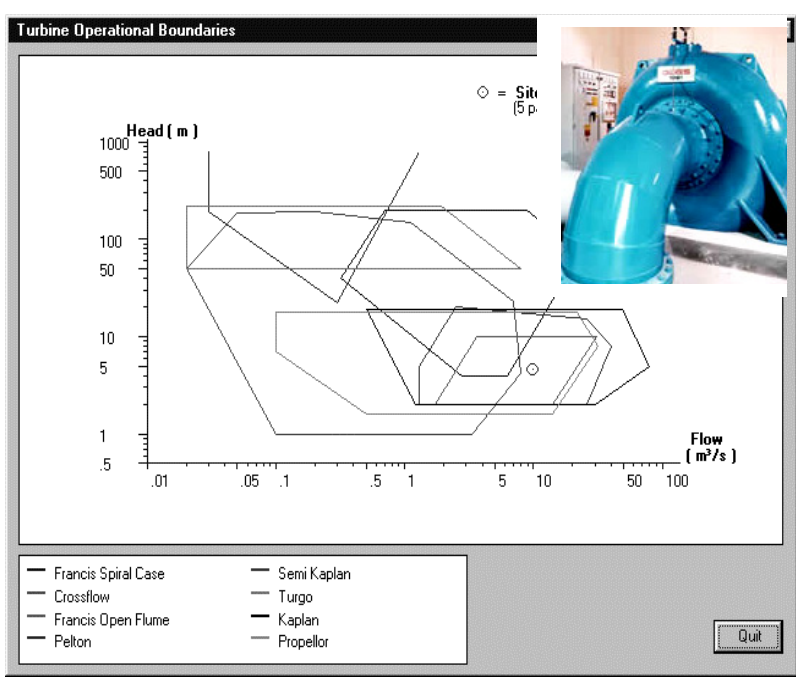

Fig. 5: Example output from HydrA [1] of the turbine operational boundaries; inset is a Francis turbine installed in Blackburn Wastewater Treatment Works.

Each design will have its own specific characteristics and components including storage, culvert, penstock, turbine house and tailrace system, whose values will be adjusted for each location, [12, 13].

\section{D. (WP4) Environmental implications}

The often ad hoc and loosely defined approaches to defining impacts of hydro power schemes on a water course are currently being reviewed by various licensing bodies.

This WP is an opportunity to ensure the environmental implications of a hydro scheme, such as a water abstraction licence and environmental impact assessment are at one with current environmental legislation. To this end the project is in consultation with the Environment Agency to help ensure all parties are considered, [14], (figure 6).

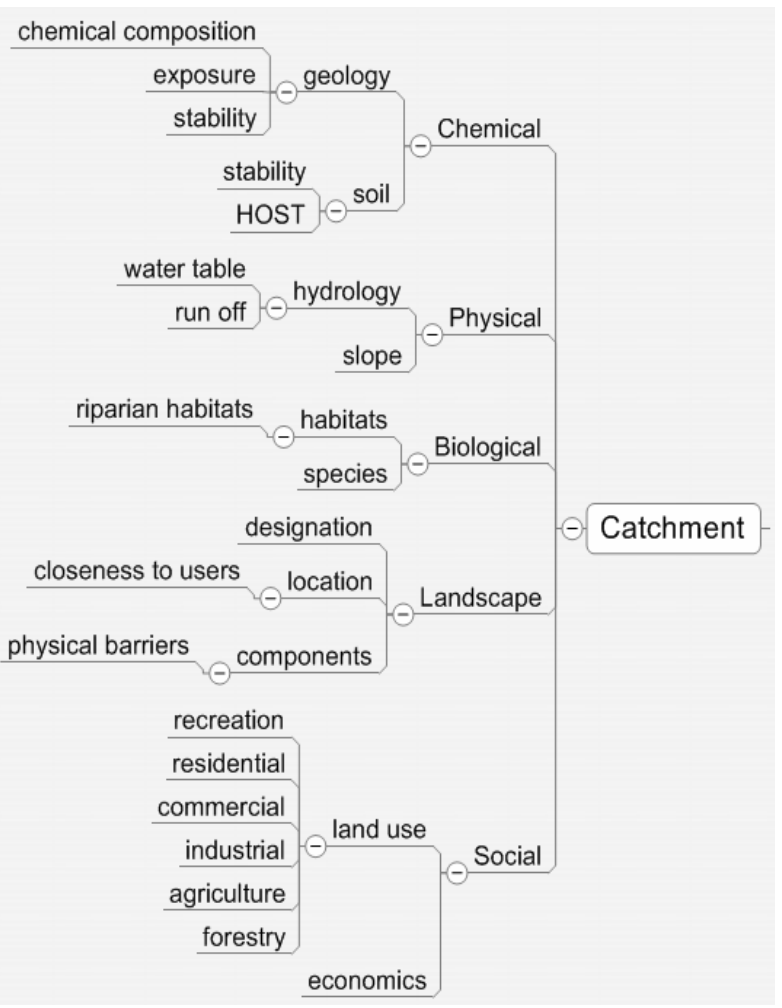

Fig. 6: Illustration of part of the thought process before a hydro power system is approved in a particular location.

\section{E. (WP5) Public engagement}

How the public engage with hydro technology is a crucial question this WP is seeking to address. Ordinary people are potential adopters of the technology at a micro household and community level and may be concerned about the local impacts of the installation (visual, ecological, noise etc.). The research here will focus on recognising the diversity of public and stakeholder groups who may have an interest in the installation and impacts of small scale hydro technologies.

\section{F. (WP6) Dissemination and exploitation}

The final work package will ensure the project delivers its objectives and outputs and identifies future work on technologies and legislation that can smooth the path for potential hydro power designers, installers and end users. The novelty of this project is its ability to identify appropriate solutions to different situations and locations. The outputs will not be a "one size fits all" approach, but offer a range of options that will have different capacities, values and costs.

\section{Case Study - Sizergh Estate, Sedgwick, CUMBria, UK}

The River Kent runs southward alongside the easterly border of the Sizergh estate and contains the New Sedgwick Gunpowder Works (NSGW) site. A second 
site, Old Sedgwick, is located $1 / 4$ mile downstream on the opposite bank of the river.

The final site along the Kent, Basingill, is located $1.2 \mathrm{~km}$ further downstream from NSGW on the opposite side of the river. The three locations were once elements of a wider network of seven sites that were part of the Cumbrian gunpowder industry in the South-East of the county [15]. The seven sites can be seen below in figure 7.

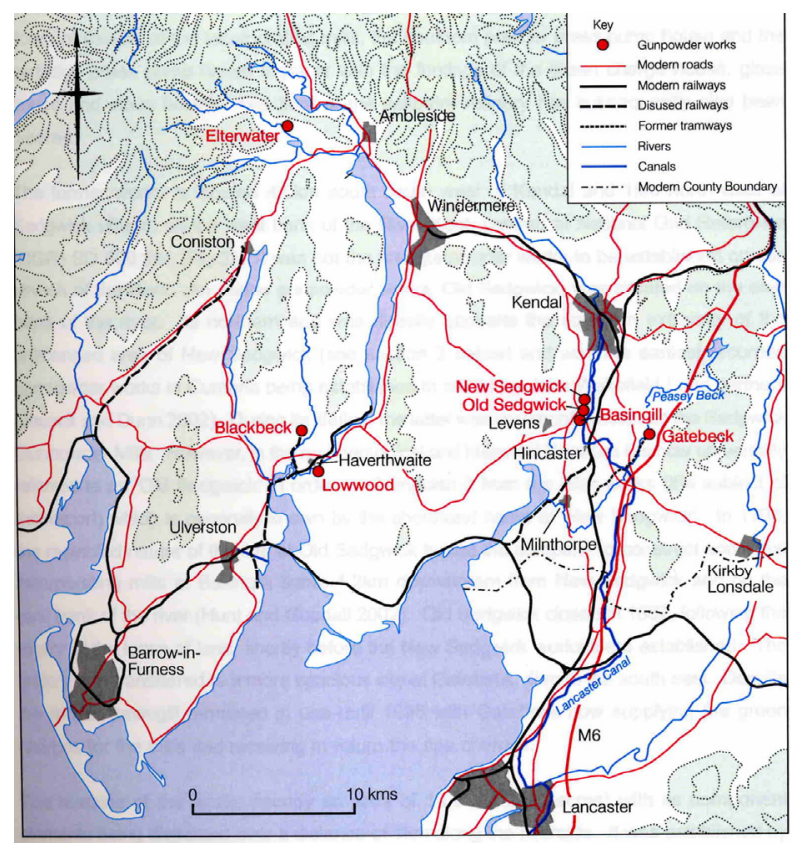

Fig. 7: Map to show the location of the seven Gunpowder Works Sites in South-East Cumbria; (C) English Heritage, [15].

The industry relied on the civilian needs for the gunpowder, and supplied the mines and quarries in the north of England with blasting powder. This was an effective alternative to the hub of the industry; located in the South of England, primarily around London, which served the military market and allowed the dangerous processes to be carried out in the relative safety of the secluded locations the area provided. Old Sedgwick was the earliest recorded gunpowder works in Cumbria; being established in 1764 by John Wakefield I and partners. In 1790 the company was forced to construct additional mills at Basingill. The site closed in 1852 following the expiry of the lease of land.

Construction started on NSGW in 1857 by William Charles Strickland, owner of Sizergh Castle and its estate (figure 8), but by 1864 his company had failed and had been taken over by a syndicate from Manchester. The industry declined sharply after World War I when there was a collapse in the demand for many of the Lake District's mineral resources. NSGW closed in 1935 and a number of buildings were demolished to prevent any residual gunpowder in their fabric being accidentally ignited. The last site to close was Gatebeck in 1936. The remains of the NSGW site occupy an area of 10.9 hectares (26.9 acres). The site is designated a Scheduled
Ancient Monument (No 27807) and a number of its upstanding remains are also Listed Buildings (Grade II).

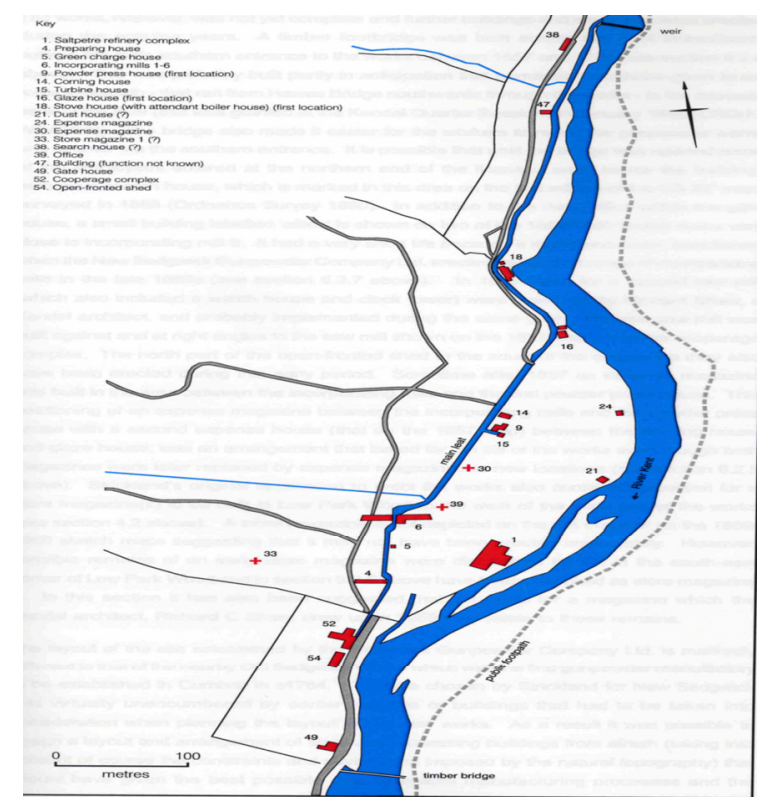

Fig. 8: Location of New Sedgwick Gunpowder Works on the River Kent showing the $845 \mathrm{~m}$ Leat from Larkrigg to Cooper's Yard; (C) English Heritage, [15].

Figure 9, below shows an artist's interpretative sketch of the hydro power arrangement at New Sedgwick Gunpowder Works. The incorporating mills were built in two ranges set at an angle to each other and separated by a blast wall [16].

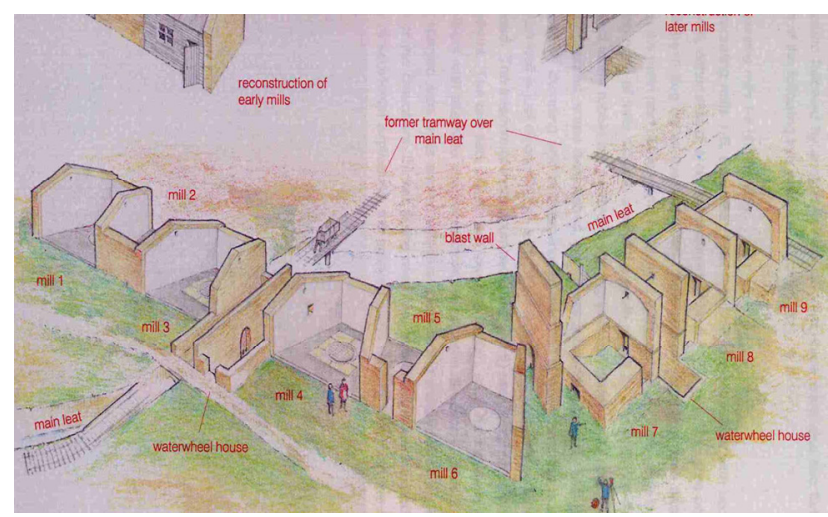

Fig. 9: Partial site reconstruction sketch by English Heritage of the incorporating mills at New Sedgwick Gunpowder Works; (C) English Heritage, [15].

The National Trust (NT) acquired the site in 1950 and maintains a few of the buildings south of the works. Recently local tenants and the Trust have shown an interest in renovating the works at NSGW with the purpose of once again producing energy from the waters of the Kent. With this in mind the authors of the northwest hydro resource model are working with the NT and using the NSGW site as a case study. Figure 10 shows the old water wheel housing at the NSGW site. 


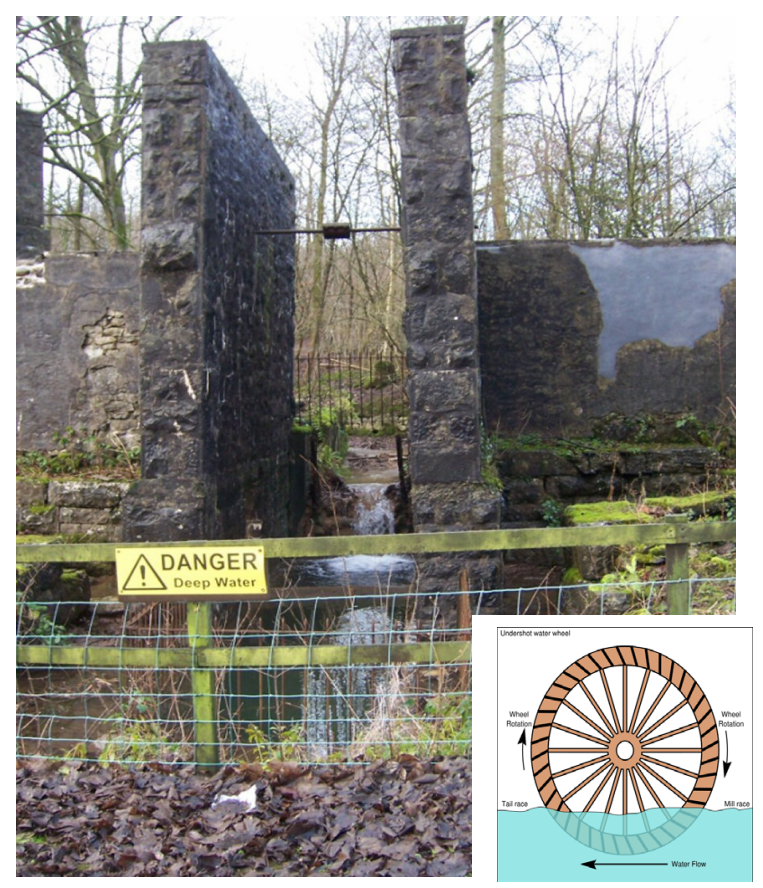

Fig. 10: Water wheel housing at Sedgwick Gunpowder Works; inset illustrates an example of an undershot waterwheel which could have been utilized at Sedgwick.

A preliminary site visit is followed by a desk study using Low Flows 2000 which estimates the flow (resource) from gauged data on the River Kent. Table 1 shows the catchment characteristics and annual mean flow along with mean monthly flows. Numbers in bold signify highest and lowest monthly flows.

TABLE I

RIVER KENT CATCHMENT CHARACTERISTICS AND MEAN FLOW STATISTICS

Basin details: Basin area:

Rainfall (average annual):

Potential evaporation

(average annual):

Runoff (average annual):

Base-Flow Index:

\begin{tabular}{|c|c|c|}
\hline Mean Flow Statistics & $\underline{\left(\mathbf{m}^{3} / \mathbf{s}\right)}$ & Q95 $\left(\mathrm{m}^{3} / \mathrm{s}\right)$ \\
\hline Annual & 9.005 & 1.061 \\
\hline January & 14.51 & 2.727 \\
\hline February & 10.9 & 1.964 \\
\hline March & 10.99 & 2.433 \\
\hline April & 6.641 & 1.659 \\
\hline May & 4.674 & 1.081 \\
\hline June & 3.711 & 0.851 \\
\hline July & 3.623 & 0.672 \\
\hline August & 5.233 & 0.628 \\
\hline September & 7.074 & 0.845 \\
\hline October & 11.21 & 1.504 \\
\hline November & 13.98 & 2.371 \\
\hline December & 15.51 & 2.78 \\
\hline
\end{tabular}

The River Kent catchment with its tributaries is shown in figure 11. Before any abstract license is issued on the
Kent, the current water abstraction activity would be assessed from the current Catchment Abstraction Management Strategy (CAMS) report [14].

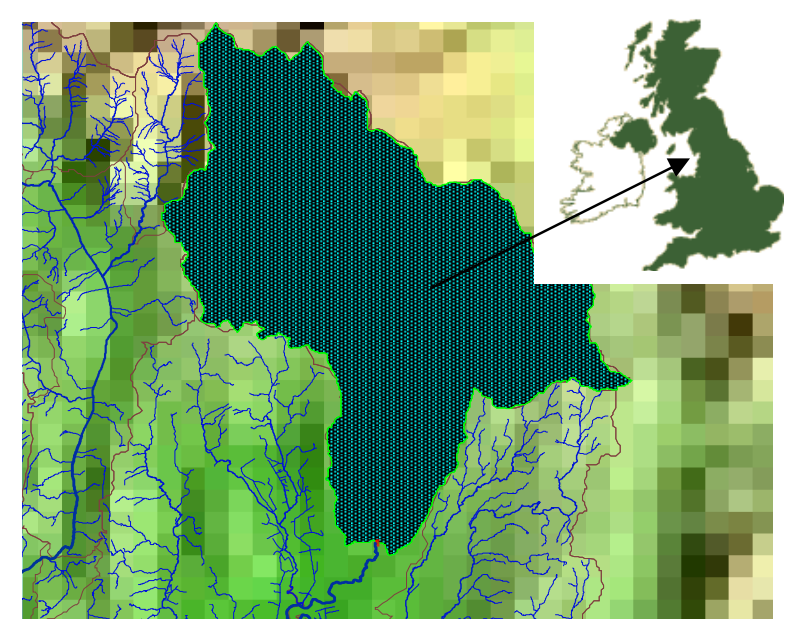

Fig. 11: River Kent catchment area, Cumbria, England [8].

\section{A. Low Flows 2000}

The mean flow for any given channel is estimated using a deterministic model calibrated on observed flow data from over 500 gauged catchments in the United Kingdom. While the annual FDC model incorporated within Low Flows makes use a 'region of influence (ROI)' approach to hydrological regionalisation. Dimensionless, observed flow duration statistics from catchments 'similar' to the user-defined catchment are combined to estimate statistics for that catchment. Similarity is defined using a Euclidean metric based on catchment characteristics [17]. A similar ROI approach is applied to estimate the proportion of annual runoff distributed over each month. Monthly flow duration curves are estimated from dimensionless observed monthly FDCs using an ROI model identical to the annual FDC model. The estimates of monthly mean flows are then used to rescale these dimensionless curves to flow units [18].

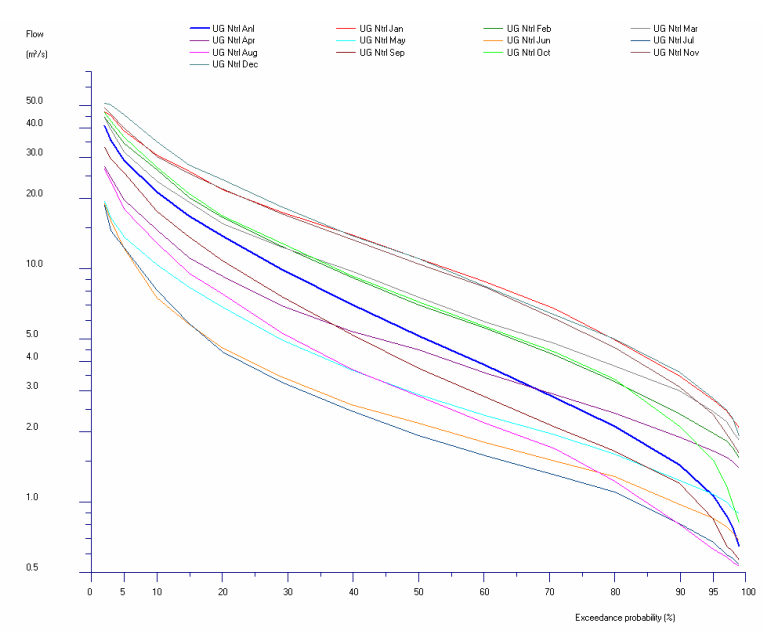

Fig. 12: Flow Duration Curves for the River Kent at Sedgwick [17]. 
Flow duration curves were derived from Low Flows 2000 (figure 12). The thick blue line shows the mean annual flow while the lower curves are the summer months (low flow period) and top curves winter/spring (high flow period). A residual flow must always be left to pass over the weir and down the fish pass (the Kent is a salmon river) and this will be stipulated within the license required for the scheme. On the basis of previous schemes, and initial consultations with the EA this has been assumed to be equal to the Q95 flow (this means that for $5 \%$ of the year the flow will be at this level or below). The residual flow and the existing abstractions are subtracted from the measured flow to give the actual flow available for power generation.

\section{B. Turbine choice}

For a low head site such as this, options considered include: Kaplan, Crossflow, Banki type, Ossberger, Archimedean screw or propeller turbine. The Kaplan which is an axial flow reaction turbine specifically designed for low head operation would be an appropriate choice. A bulb turbine is similar to a Kaplan turbine, but with the generator enclosed in a waterproof bulb within the flow. If a Kaplan turbine is used it would be sensible for it to be "double-regulated", i.e. for both the guide vanes and the blades to be adjustable. This is because of the large range of flows occurring at the site and the need to accommodate them, $[11,12]$.

The original turbine installed at NSGW was manufactured in Kendal by Gilbert Gilkes and Gordon Limited, [19].

\section{Power generation}

The total power available in the section of river considered will vary according to the time of year. In general terms the total power available can be expressed by:

$$
P=Q H \gamma \eta
$$

Where: $P=$ Power $(\mathrm{kW})$

$$
\begin{aligned}
& Q=\text { Flow }\left(\mathrm{m}^{3} / \mathrm{s}\right) \\
& H=\text { Gross head }(\mathrm{m})
\end{aligned}
$$$$
\gamma=\text { Specific Weight of Water }\left(9.81 \mathrm{kN} / \mathrm{m}^{3}\right)
$$

Assuming $\rho$ density of cold clean water is $1000 \mathrm{~kg} / \mathrm{m}^{3}$ and $\mathrm{g}$ acceleration due to gravity is $9.81 \mathrm{~m} / \mathrm{s}^{2}$ $\eta=$ Efficiency (assuming $80 \%$ efficiency)

From this formula it can be seen that the power available in the river section is potentially:

Minimum mean potential power generation (July)

$P=3.623 \times 6.4 \times 0.8 \times 9.81=\mathbf{1 8 2} \mathbf{k W}$

Maximum mean potential power generation (December)

$P=15.51 \times 6.4 \times 0.8 \times 9.81=778 \mathrm{~kW}$
Annual mean potential power generation

$P=9.005 \times 6.4 \times 0.8 \times 9.81=\mathbf{4 5 2} \mathbf{k W}$

The Capacity Factor (CF) is a ratio summarizing how hard a turbine is working, expressed as:

$$
\begin{aligned}
\mathrm{CF}= & \text { Energy generated per year }(\mathrm{kWh} / \text { year }) / \\
& \text { Installed capacity }(\mathrm{kW} \text { x } 8760 \text { hours/year }
\end{aligned}
$$

Annual energy output is estimated from an assumed Capacity Factor (CF) of 35\% as follows:

Energy $(\mathrm{E}),(\mathrm{kWh} /$ year $)=\mathrm{P}(\mathrm{kW}) \times \mathrm{CF}$ x 8760

$\mathrm{E}=452 \times 0.358760$

$\mathrm{E}=1385832 \mathrm{~kW} /$ year

Annual revenue $=\mathrm{E} x$ Unit Cost $(\mathrm{p} / \mathrm{kW})$

Annual revenue $=1385832 \times 0.06=\mathbf{\$ 8 3 , 1 5 0}$

From (10) above the payback period for a hydro scheme costing $£ 200 \mathrm{~K}$ is around 2.4 years and 3.6 years for a scheme costing $£ 300 \mathrm{~K}$. However, these feasibility figures are only a guide. A detailed study and costing would be undertaken if the NT and interested parties wished to follow the proposal to restore NSGW and generate hydropower on the River Kent at Sedgwick.

The large differences in potential power output throughout the year show how it is important that the correct type of generator is selected. These calculations have been made using gross head and it should be noted that the net head could be considerably lower, especially with the long length of the leat. Additionally, an efficiency of $80 \%$ has been used in the above calculations, and not all turbines will necessarily be this efficient.

\section{Restrictions}

One initial major concern voiced by the Environment Agency (EA) regarding the redevelopment of NSGW is the present length of the Leat $(845 \mathrm{~m})$. This means that water is displaced from the Kent for a considerable distance and the EA has concerns that this may harm the ecology of the river. This could be possibly be solved by restricting the proportion of the total flow diverted through the turbine. An alternative attempt to draw the water from the river further downstream of the Larkrigg weir was proposed at a weir that pre-dated the gunpowder works. This can be seen in figure 13 below.

\section{E. Cost analysis}

The extensive redevelopment required will incur a considerable cost, not only with the mechanical equipment needed but also civil works on the weir, leat, turbine housing and any educational centre required. A study by Liverpool John Moores University in 1998 [16], 
estimated that reconstructing the weir would cost roughly $£ 30,000$ and the Leat would cost about $£ 100$ per metre to repair to a useable standard (giving a total of roughly $£ 84,500$ for its repair). Assuming that inflation has been roughly $2.5 \%$ in the intervening years this would give a 2007 price of roughly $£ 38,000$ for the weir and $£ 103,000$ for the leat.

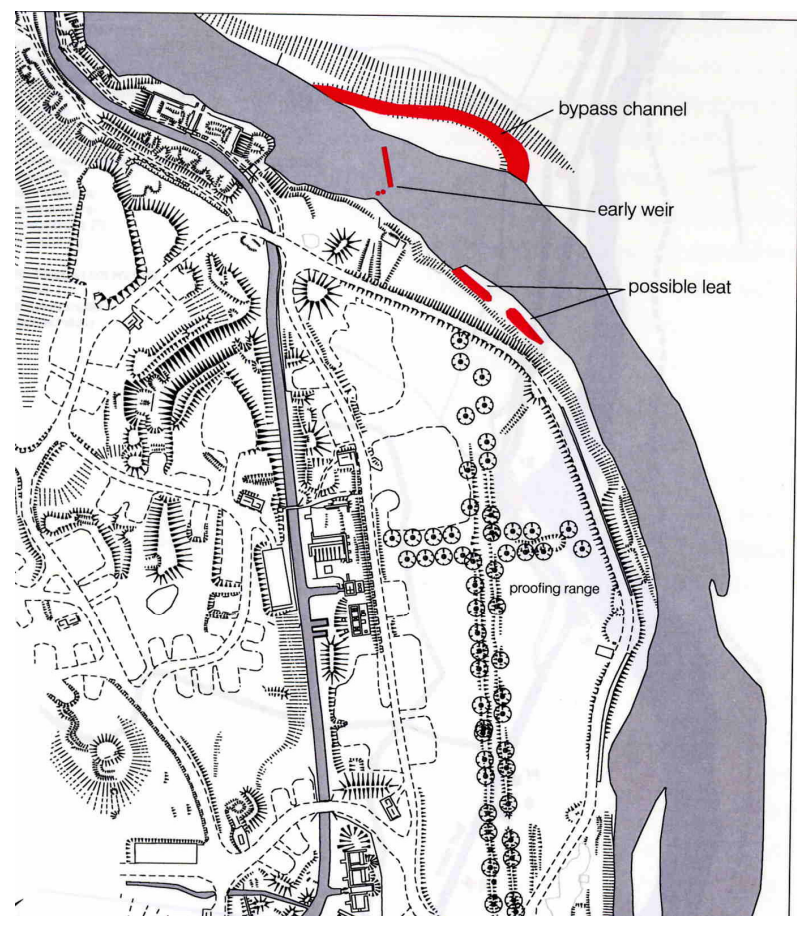

Fig. 13: Map to show the site of a weir that pre-dates the Sizergh Gunpowder Works; (C) English Heritage, [15].

In addition to this there would be the cost of the turbine and turbine housing itself, which would typically be between $£ 60,000$ and $£ 165,000$ The final total could reach up to $£ 300,000$ when the costs of the educational buildings are taken into consideration. Alternatively, this value could be as low $£ 200,000$. It should be noted that Kaplan turbines have been found to be more expensive than propeller turbines although they are more efficient in operation.

\section{CONCLUSIONS}

As bulk electricity supply from large utilities became more generally available many small hydro schemes fell into disuse. Since 1980, small hydro schemes have shown strong development in many countries, supported by favorable political measures. Today, revival of similar schemes in Britain by re-planting into existing infrastructure or refurbishment of old plants can be cost effective and make a useful contribution to renewable energy production; there are also a large number of previously unconsidered sites. Small hydro is also well suited for integration into existing infrastructure, and particularly on water supply schemes since major civil engineering structures are already in place. An imaginative development of such schemes leads to power generation where the energy was previously dissipated.
The development of a model is described that integrates the disciplines necessary to develop the hydro application in the North-West of England.

The model is composed of a series of integrated submodels addressing the barriers to installation of devices as seen through different disciplines. The information is linked through an economic assessment which identifies different turbine options, assesses their suitability for location and demand and combines the different styles of information in a way that supports decision making. There are five sub-model components; the hydrological resource is modelled using Low Flows 2000 which is being extended to improve coverage of smaller ungauged rivers, the turbine options will be identified from hydrological, environmental and demand requirements and the consequences of the different solutions will be fed into the other components so that the environmental impacts and public acceptability can be assessed and valued. The model also feeds information into the hydrological resource estimates so that the consequences of multiple installations can be assessed.

The modelling approaches being employed differ within each component, using mathematical, statistical and cost-benefit approaches. The outputs will be presented in a range of formats enabling use of the results to be made by different users. The model is seen as a tactical tool that will operate at the level of individual low- and ultra-low head hydro installations and there is interest from potential users across a range of scales from large utilities and national agencies to local manufacturers.

The development of the model includes field validation of any forecast figures and will identify the necessary monitoring and gauging to identify measures that can rapidly and easily taken to confirm the confidence in the proposed solution.

Any redevelopment of the Gunpowder Works at Sedgwick would require an extensive environmental impact assessment, along with a detailed planning application. The payback period on such a scheme is likely to be long. Linking to the National Grid may be complex and downtime and maintenance costs must be considered. However, if sufficient interest is shown grant support may make the project viable.

Historically water power was utilised for centuries to drive machinery in mills and factories. It determined the location of industry, supported the industrial revolution and shaped the landscape of the North West, but since the end of the $19^{\text {th }}$ century its importance declined as fuel powered engine technology flourished. However, perhaps it is time to revisit the potential of this overlooked resource that is literally flowing past our front doors. This project is in its infancy, but has potential to be applied throughout the UK.

\section{APPENDIX}

Appendix 1: Scale Map of Buildings and Features of New Sedgwick Gunpowder Works [15]. 


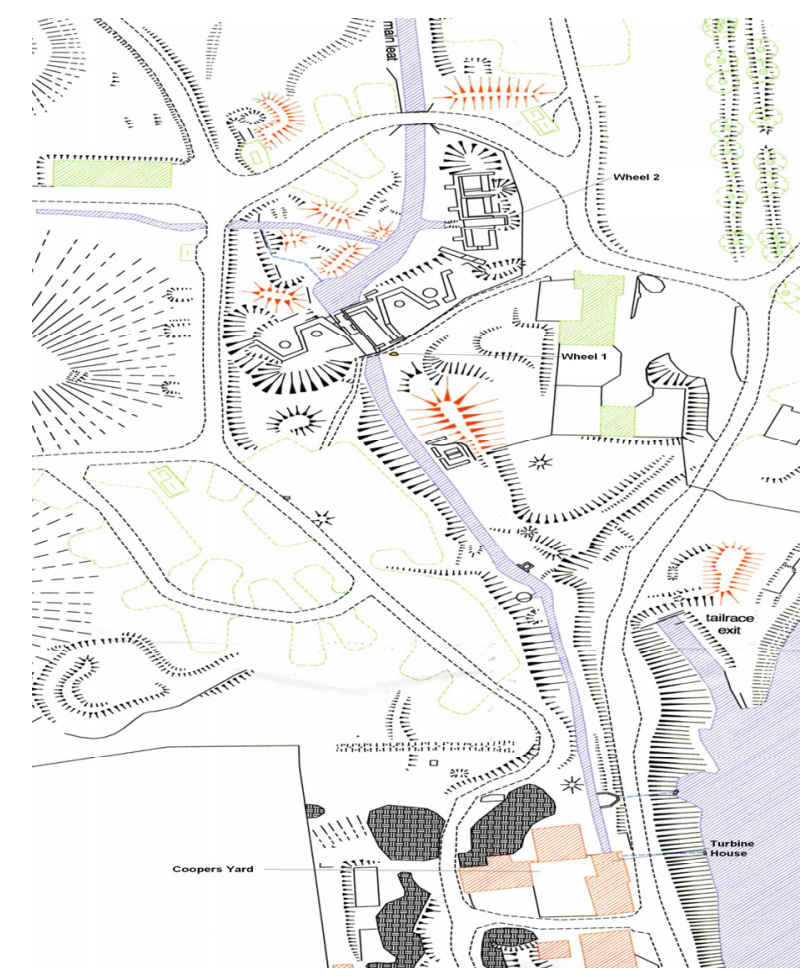

[1] Fig. 14: Scale Map of Buildings and Features of New Sedgwick Gunpowder Works; (C) English Heritage, [15].

\section{ACKNOWLEDGMENTS}

The authors wish to express their appreciation of the support of the North West Development Agency (NWDA) through the Joule Centre for Energy, for the research reported in this paper via Joule Grant Reference: JIRP106/07.

Further thanks to English Heritage and Ordinance Survey (license number GD03085G) for permission to reproduce figures 7, 8, 9, 14 and 15 from: "New Sedgwick Gunpowder Works, Cumbria", an archeological and architectural survey [15].

\section{REFERENCES}

[1] UK Department of Trade and Industry,: “The Energy Challenge: The Energy Review Report July 2006, Cm 6887.

[2] Aggidis, G. A., Howard, D. C., Rothschild, R., and Widden, W. B.: Maximising the benefits of hydropower by developing the North-West England hydro resource model, Proceedings of the International Hydro Power and Dams Construction Journal, Paper 7.01, HYDRO 2006 Maximising the benefits of Hydropower, Porto Carras, Greece, 25-27 September 2006.

[3] Aggidis, G A.: Resourceful Solutions, International Water Power and Dam Construction Journal, September 2006, pp, $24-26$.

[4] Howard, D.C., Aggidis, G .A., and Wright, S. M.: A hydro power resource model for north west England, Proceedings of the fourteenth annual IALE(UK) conference, Oxford Brookes University, Water and the Landscape: The Landscape Ecology of Freshwater Ecosystems, Edited by Bella Davies and Stew art Thompson, September 2006, pp 41-46.
[5] Howard, D.C., Aggidis, G .A., Wright, S .M., and Scott, R.: Energy Source or Sink? The Role of the Uplands in meeting our Energy Targets, Proceedings of the International Uplands Centre Conference on Sustainable Uplands, 30 May to 1 June 2006, Kendal, Cumbria, UK.

[6] Read, P. \& Lermit, J.: Bio-energy with carbon storage (BECS): A sequential decision approach to the threat of abrupt climate change. Energy, 30, 2005, pp. 2654-2671.

[7] Wolters., W. T. M., Lambert, A J. .D. \& Claus, J.: Sequencing problems in designing energy efficient production systems. International Journal of Production Economics, 1995, 41, pp. 405-410.

[8] Leigh, P. A.: Time to go with the flow, Water \& Environment Magazine, vol. 12, No. 3, March 2007 pp. 24-25.

[9] Holmes, M. G. R.; Young, A. R., Goodwin, T. H.; and Grew, R.: A catchment-based water resource decisionsupport tool for the United Kingdom, Environmental Modelling \& Software, Vol. 20 Issue 2: 2005, pp. 197-202.

[10] Aggidis, G. A.: Technological Developments on Small Hydro, Invited Paper, IMechE Fluid Machinery Group, London, May 2001.

[11] Nechleba, M.: "Hydraulic Turbines, Their Design and Equipment", Constable London 1957.

[12] Aggidis, G .A., Graves, C. P., and Porter, N. I.: "Experience of Innovation \& Technological Developments Meeting Small Hydro Needs Today", Proceedings, International Conference on Small Hydro, Athens, Greece, November 1998.

[13] Mosonyi, E.: "High Head Power Plants", Academiai Kiado, Budapest 1991.

[14] Environment Agency.: The Kent Catchment Abstraction Management Strategy (CAMS) Report, March 2004.

[15] Dunn, C., Lax, A., Hunt, A., Jecock, M., Goodall, I., Berry, T., Taylor, S.: "New Sedgwick Gunpowder Works Cumbria: An Archaeological and Architectural Survey". 2003.

[16] Clare, T.: The potential of former water power sites to contribute to sustainable development, unpublished report, Liverpool John Moores University, 1998.

[17] Holmes, M. G. R, Young, A. R., Gustard A .G., and Grew R.: A Region of Influence approach to predicting Flow Duration Curves within ungauged catchments. Hydrology and Earth System Sciences 6 (4), 2002, pp. 721-731.

[18] Young, A R, Grew, R \& Holmes, M. G. R.: Low Flows 2000: a national water resources assessment and decision support tool. Water Science \& Technology Vol.48 No.10, 2003, pp 119-126.

[19] Wilson, P.: Gilkes 1853 to 1975, 122 Years of water turbine and pump manufacture, Science Museum, London 1975. 